\title{
USE OF THE HYPOSPRAY JET INJECTOR FOR INTRA-ARTICULAR INJECTION
}

\author{
BY \\ JOHN BAUM* AND MORRIS ZIFF \\ From the Department of Internal Medicine (Rheumatic Diseases Unit), University of \\ Texas Southwestern Medical School, and the Arthritis Clinical Centre $\dagger$, Parkland Memorial Hospital \\ Dallas, Texas, U.S.A.
}

The hypospray jet injector is a device to inject medication under pressure through the skin and subcutaneous tissue into the deeper connective tissue structures. Its efficacy for intra-articular injection was first reported by Ziff, Contreras, and Schmid (1956).

\section{Method of Use}

The hypospray, as employed by Ziff and co-workers and in our subsequent investigations, utilized metapules (metal containers, one ml. in volume) containing the medication; it thus required reloading for each injection. A new device equipped with a multiple-dose reservoir has been released for commercial distribution and described by Rankin and Good (1966). Pietschmann (1964) reported similar results to those previously published using a multiple-dose type injector in 96 patients.

Power for the hypospray is supplied by steel springs which, in the instrument used in the present studies, generate a pressure of approximately $350 \mathrm{lb}$. This pressure is transmitted to the orifice of the metapule by a magnifying assembly, developing approximately $16,000 \mathrm{lb}$. per square inch at the orifice. (Some of the injections were given with an instrument developing 20,000 lb. per square inch). The diameter of the orifice is $0.0086 \mathrm{in}$. An adjustable sleeve permits the injection of graded doses.

The metapules contained either 10 or $20 \mathrm{mg}$. triamcinolone acetonide (E. R. Squibb and Sons), 10 or $20 \mathrm{mg}$. prednisolone tetrabutyl acetate (Merck, Sharp and Dohme), or 25 or $50 \mathrm{mg}$. hydrocortisone acetate (Merck, Sharp and Dohme), each in one $\mathrm{ml}$. of vehicle. Large joints were injected with one ml. steroid suspension and small joints with amounts varying from 0.2 to $1 \mathrm{ml}$., depending on the size of the joint.

Large joints, such as the knee, ankle, wrist, and elbow, have been injected without difficulty. The hip joint, which is not accessible to the hypospray, was not injected. All small joints of the hand and foot, the temporomandibular, and costochondral joints, have been injected.

Injections by hypospray are given by holding the tip firmly against the skin, and aiming the orifice toward the joint space. The skin site is cleansed with alcohol in the usual manner. In injecting the metacarpophalangeal joints, distraction of the joint has been found to be helpful.

*Clinical Scholar, The Arthritis Foundation.

tSupported by a grant from The Arthritis Foundation.
Injection of the proximal interphalangeal joints was made with the joint in flexion while the patient grasped a rounded object. When the subacromial bursa or an area of epicondylitis is injected, the injection is given over the point of maximal tenderness. Since the hyposprayed material tends to distribute itself from the point of entry in a radial manner, there is a somewhat greater latitude in the direction in which the hypospray is pointed than is available with needle injection.

\section{Results}

Our experience with the hypospray consists of 753 injections given to 228 patients with various rheumatic conditions.

Improvement was graded as moderate to marked, minimal, or none. A minimal response was one which showed minor improvement for less than a week. A moderate response was one in which there was a significant decrease in pain and joint swelling, which persisted for from 1 to 3 weeks. A marked response was one in which there was almost complete relief of pain and swelling for a period lasting over 3 weeks.

Rheumatoid Arthritis.-The results of 486 injections in 152 patients with either juvenile or adult rheumatoid arthritis are given in Table I. Improvement was graded as moderate to marked or minimal

TABLE I

RESULTS OF INJECTION OF STEROID BY HYPOSPRAY IN 152 CASES OF RHEUMATOID ARTHRITIS

\begin{tabular}{|c|c|c|c|}
\hline \multirow{2}{*}{$\begin{array}{c}\text { Joints } \\
\text { Injected }\end{array}$} & \multirow{2}{*}{$\begin{array}{c}\text { Total } \\
\text { Injections }\end{array}$} & \multicolumn{2}{|c|}{ Improvement (per cent.) } \\
\hline & & $\begin{array}{l}\text { Moderate to } \\
\text { Marked }\end{array}$ & $\underset{\text { None }}{\text { Minimal to }}$ \\
\hline $\begin{array}{l}\text { DIP, PIP, MCP, MTP, TM } \\
\text { Knee } \\
\text { Ankle } \\
\text { Shoulder } \\
\text { Elbow } \\
\text { Wrist }\end{array}$ & $\begin{array}{r}128 \\
223 \\
30 \\
17 \\
18 \\
70\end{array}$ & $\begin{array}{l}86 \\
76 \\
77 \\
53 \\
61 \\
53\end{array}$ & $\begin{array}{l}14 \\
24 \\
23 \\
47 \\
39 \\
47\end{array}$ \\
\hline Total & 486 & & \\
\hline
\end{tabular}

$\mathbf{D I P}=$ distal interphalangeal; $\mathbf{P I P}=$ proximal interphalangeal; $\mathbf{M C P}=$ metacarpophalangeal; $\mathbf{M T P}=$ metatarsophalangeal; $T M=$ temporomandibular. 
to none. The best results occurred in the small joints, where 86 per cent. of injections were followed by moderate to marked improvement. A group of these patients whose small joints were injected were followed carefully for an extended period of time. Table II shows that in these cases injection of the small joints of the hands, feet, and temporomandibular joints was followed by prolonged improvement for an average of from 6.5 to 9.3 months, depending on the joint, the best results being seen in the metacarpophalangeal joints.

TABLE II

DURATION OF REMISSION IN SMALL JOINTS AFTER INJECTION OF STEROID BY HYPOSPRAY

\begin{tabular}{c|c|c|c}
\hline \multirow{2}{*}{ Joint } & $\begin{array}{c}\text { No. of } \\
\text { Injections }\end{array}$ & \multicolumn{2}{|c}{ Duration of Remission (mths) } \\
\cline { 3 - 4 } & 20 & Median & Range \\
\hline MCP & $8 \cdot 3$ & $1-16$ \\
MTP & 38 & $7 \cdot 0$ & $7-11$ \\
PIP, DIP, TM & $3 \cdot 5$ & $0 \cdot 3-17$ \\
\hline
\end{tabular}

In the larger joints, moderate to marked improvement was noted in from 76 per cent. (knee) and 77 per cent. (ankle) to 53 per cent. of injections (wrist and shoulder).

Other Arthritides.-The following patients were treated:

Psoriatic arthritis (5), disseminated lupus erythematosus (5), scleroderma (1), arthritis with ulcerative colitis (1), degenerative joint disease (26), ankylosing spondylitis (3), Reiter's disease (3), and gouty arthritis (3).

The results in these patients were similar to those observed in the rheumatoid group.

Non-articular Rheumatism.-29 patients were treated and the hypospray was found to be particularly useful in six cases of epicondylitis or "tennis elbow". Up to six injections per patient were given at the point of maximum tenderness in the region of the lateral epicondyle. The usual duration of remission was between 2 and 3 months, but some lasted up to 3 years before recurrence.

In contrast to the experience of Steinbrocker (1966), most patients preferred the hypospray to the needle because of the lesser degree of pain and the rapidity of the injection. We have found the hypospray particularly advantageous in injecting children's joints for these reasons.

Finder and Post (1960) pointed out that care was needed to avoid trauma to joint surfaces when injecting with a needle, especially into small joints. Such trauma did not appear to occur when injecting with the hypospray injector.

Our experience indicates that this method has significant advantages over the needle for the injection of most joints.

\section{Summary}

This report presents our experience using the hypospray jet injector for local injection of steroids based on 753 injections given to 228 patients with various rheumatic conditions. 486 injections were given to 152 patients with rheumatoid arthritis; both large and small joints showed satisfactory improvement, but the greatest benefit was achieved in the small joints of the hands and feet, in which 86 per cent. of injections produced moderate to marked improvement, and the median duration of improvement ranged from 6.5 to 9.3 months. Complications were minimal, with only one joint infection in the series, an incidence of 0.013 per cent. Satisfactory results were also obtained in the treatment of other arthritides and of non-articular rheumatism. Compared to the needle, the hypospray is more rapid to use, produces less discomfort, and is more acceptable to patients, especially to children.

The hypospray jet injectors used in this study were provided by the R. P. Scherer Corporation, Detroit, Michigan.

\section{REFERENCES}

Finder, J. G., and Post, M. (1960). J. Amer. med. Ass., 172, 2021 (Local injection therapy for rheumatic diseases).

Pietschmann, H. (1964). Wien. Z. inn. Med., 45, 348 (Erfahrungen mit dem "Hypospray Jet Injector" in der lokalen Prednisolon-Therapie rheumatischer Erkrankungen).

Rankin, T. J., and Good, A. E. (1966). Arthr. and Rheum., 9, 611 (Corticosteroid injection of small joints by hypospray).

Steinbrocker, O. (1966). Ibid., 9, 362 (Letter to the Editor).

Ziff, M., Contreras, V., and Schmid, F. R. (1956). Ann. rheum. Dis., 15, 227 (Use of the hypospray jet injector for the intra-articular and local administration of hydrocortisone acetate). 
Emploi de l'injecteur à jet fin sous haute pression pour les Uso del inyector a chorro "Hypospray" para infiltración infiltrations intra-articulaires

intra-articular

RÉSUMÉ

On rapporte ici nos résultats sur l'emploi de l'injecteur à jet fin sous haute pression pour injecter localement des stéroïdes. On procéda à 753 injections chez 228 sujets présentant diverses affections rhumatologiques. A 152 malades atteints d'arthrite rhumatismale on pratiqua 486 injections; les grosses articulations comme les petites accusèrent une amélioration satisfaisante, mais on obtint le plus grand succès au niveau de petites articulations des mains et des pieds où 86 pour cent des injections produisirent une amélioration modérée ou bien nette; la durée moyenne de cette amélioration alla de 6,5 à 9,3 mois. Le taux des complications fut minime: un seul cas d' infection articulaire dans la série, ce qui constitue une incidence de 0.013 pour cent. Des résultats également satisfaisants furent obtenus dans le traitement d'autres arthrites et de cas de rhumatisme abarticulaire. Comparé à la technique standard utilisant une aiguille, ce procédé est d'un emploi plus rapide, moins désagréable et plus facilement accepté par les malades, particulièrement les enfants. 